Check for updates

The BMJ

fgodlee@bmj.com Follow Fiona on Twitter @fgodlee

Cite this as: BMJ 2020;369:m2303

http://dx.doi.org/10.1136/bmi.m2303

Published: 11 June 2020

\section{Racism: the other pandemic}

\section{Fiona Godlee editor in chief}

Racism is suddenly and at last everyone's business, and acting against it is everyone's responsibility. More so at this time than ever, we now realise, since we cannot tackle covid-19 unless we tackle racism. This realisation may be less obvious to some, who see the global outpouring of grief and anger at the killing of George Floyd in Minneapolis as either a distraction from or in conflict with efforts to contain the virus. Commentators in The BMJ make it clear that these two things are deeply interconnected and must be dealt with together. Racism is a public health issue because it kills people (doi:10.1136/bmj.m2244). It is the underlying driver that puts people from ethnic minority groups at the centre of the pandemic. It is a co-factor for covid-19 and a key social determinant of health

(https://blogs.bmj.com/bmj/2020/06/08/structuralracism-in-society-and-the-covid-19-stress-test).

No effective response to covid-19 can ignore these factors. Sadly, that's what Public Health England's report just published has largely done, sparking its own outpouring of protest from ethnic minority groups across the UK (doi:10.1136/bmj.m2264). Billed as a review into ethnic disparities and covid-19, it devotes only a small proportion of its pages to ethnicity, and, while confirming what we knew-that people from ethnic minority groups are more likely to become infected and to die from covid-19-it makes no attempt to explain the disparities or make recommendations for action.

“A missed opportunity," say Parth Patel and colleagues (doi:10.1136/bmj.m2282). Zubaida Haque and colleagues are dismayed that "the government has effectively discovered who is dying from covid-19 with no strategy or recommendations as to what to do about it"

(https://blogs.bmj.com/bmj/2020/06/o8/if-the-ukhealth-sector-does-not-address-structural-racismthen-more-black-and-minority-ethnic-lives-will-belost). Covid-19 has produced a "stress test" for structural racism in healthcare and public health, say Christine Douglass and colleagues (https://blogs.bmj.com/bmj/2020/06/08/structuralracism-in-society-and-the-covid-19-stress-test). It is crucial to scrutinise the causes of health and social care inequality to reduce the risk of further infections and deaths.

Despite Public Health England's silence there is no shortage of suggestions for what to do, in both the immediate and long term (doi:10.1136/bmj.m2264; https://blogs.bmj.com/bmj/2020/06/o8/covid-19-inethnic-minority-groups-where-do-we-go-followingphes-report). These must include tailored and multilingual communications on test, track, and isolate measures (doi:10.1136/bmj.m2122). Above all, now is the time for clinicians and public health experts to take a firm stance against racism, say
Abraar Karan and Ingrid Katz

(doi:10.1136/bmj.m2244). If you have a platform, use it to speak out, they say. The BMJ's special issue on racism in medicine in February is one contribution (bmj.com/racism-in-medicine). The NHS's response in setting up a Race and Health Observatory is another (doi:10.1136/bmj.m2191).

If we can see racism for what it is, a scar on society that damages us all, and if we can act to tackle it in all its forms, then the light that covid has shone on racism will guide us to a better place. 